\title{
Artikkeli
}

Prologi - puheviestinnän vuosikirja 2020

44-57

https://doi.org/10.33352/prlg.99516

\section{Päivällisellä vieraan kanssa: parasosiaalinen kohtaaminen immersiivisessä virtuaaliympäristössä}

Venla Kuuluvainen

FT, tutkija

Informaatioteknologian ja viestinnän tiedekunta, Tampereen yliopisto

venla.kuuluvainen@tuni.fi

\section{Lassi Rikkonen}

FM, väitöskirjatutkija

Informaatioteknologian ja viestinnän tiedekunta, Tampereen yliopisto

lassi.rikkonen@tuni.fi
Ira A. Virtanen

FT, asiantuntija

Tutkijakoulu, Tampereen yliopisto, ira.virtanen@tuni.fi

\author{
Pekka Isotalus \\ professori \\ Informaatioteknologian ja viestinnän tiedekunta, \\ Tampereen yliopisto \\ pekka.isotalus@tuni.fi
}

\section{Tiivistelmä}

Parasosiaalinen kohtaaminen vieraaksi koetun ihmisen kanssa mahdollistaa hänen ymmärtämisensä moniulotteisena, yksilöllisenä olentona yleistävän kulttuurisen luokittelun sijasta. Tässä tutkimuksessa ${ }^{1}$ selvitimme, (1) miten parasosiaalinen kohtaaminen immersiivisessä virtuaaliympäristössä on yhteydessä katsojien ahdistuksen tunteeseen (intergroup anxiety) sekä käsityksiin vieraasta ja (2) millaiset interpersonaaliset tekijät ovat merkityksellisiä kohtaamisessa. Kohtaamisia tarkastellaan parasosiaalisten ilmiöiden näkökulmasta. Tutkimus hyödynsi immersiivistä dokumenttia, Dinnertime $360^{2}$, jossa katsoja tutustuu itselleen vieraaseen ihmiseen immersiivisessä virtuaaliympäristössä, päivällispöydässä. Tulokset osoittivat, että suhtautuminen vieraaseen muuttui kohtaamisen jälkeen myönteisemmäksi ja katsojien ahdistus väheni. Laadullinen aineisto osoitti samanlaisuuden, erilaisuuden ja hyödyllisyyden merkittäviksi interpersonaalisiksi tekijöiksi kohtaamisessa. Lopuksi pohditaan immersiivisen teknologian ja parasosiaalisten ilmiöiden suhdetta.

ASIASANAT: immersiivisyys, parasosiaalinen kohtaaminen, parasosiaaliset ilmiöt, ryhmien väliset suhteet, vieraus, virtuaalitodellisuus

${ }^{1}$ Tutkimus on osa Koneen säätiön rahoittamaa "Käy pöytääni, vieras! Päivälliset naapuridialogia edistämässä” -hanketta.

${ }^{2}$ Dinnertime 360 on Lyftan immersiivisen tarinankerronnan alusta. 


\section{Kontaktiteoria ja parasosiaaliset ilmiöt}

Ihmiset kokevat usein epävarmuutta, sosiaalista jännitystä ja ahdistusta kohdatessaan oman sisäryhmänsä ulkopuolisia ihmisiä eli vieraita henkilöitä (Duronto ym., 2005; Gudykunst, 1998; Neuliep, 2012; Stephan, 2014). Vierauden kokemusta voi vahvistaa esimerkiksi havainto erilaisesta etnisestä taustasta, iästä, koulutuksesta tai asuinpaikasta. Toisaalta samat havainnot saattavat myös motivoida tutustumaan vieraaseen.

Useat tutkimukset ovat osoittaneet, että myönteinen - ja jopa neutraaliksi koettu - kohtaaminen vähentää ihmisten välisiä ennakkoluuloja (ks. meta-analyysi Paluck ym., 2019; Pettigrew \& Tropp, 2006). Alun perin Gordon Allportin vuonna 1954 kontaktihypoteesiksi nimeämä teoria (Pettigrew \& Tropp, 2005) jalostui myöhemmin Pettigrewn (1998) kritiikistä nykyiseksi kontaktiteoriaksi. Tässä artikkelissa käytämme kontaktin sijaan paremmin suomen kieleen kääntyvää sanaa kohtaaminen, jolla viitataan vuorovaikutustilanteeseen kokonaisuutena. Tutkimuksessa tarkastelemme immersiivisessä virtuaaliympäristössä (IVY) tapahtuvia kohtaamisia parasosiaalisuuden näkökulmasta.

Parasosiaalisissa kohtaamisissa eri ryhmiin, esimerkiksi etnisyyden, iän tai seksuaalisuuden perusteella, luetut henkilöt kohdataan audiovisuaalisen viestinnän kautta (Liebers \& Schramm, 2019; McLaughlin ym., 2018; Schiappa ym., 2005; Wong ym., 2017; Wu ym., 2018). Fiktiivisten ja ei-fiktiivisten henkilöiden esiintyminen audiovisuaalisissa kanavissa vaikuttaa positiivisella tavalla katsojien asenteisiin (Igartua \& Frutos, 2017; Schiappa ym., 2006). Esimerkiksi Wong ym. (2017) havaitsivat, että parasosiaaliset kohtaamiset kaksisuuntaisesta mielialahäiriöstä kärsivän kanssa vähensivät sairastuneita kohtaan koettuja kielteisiä stereotypioita. Schiappa ym. (2006) todensivat Will \& Grace -ohjelman katsomisen vähentävän homoseksuaalisia ihmisiä kohtaan koettuja ennakkoluuloja. Shim ym. (2012) puolestaan tutkivat amerikkalaisten draamojen katsomisen vaikutuksia korealaisten nuorten asenteisiin yhdysvaltalaisia kohtaan ja havaitsivat, että parasosiaalisella kohtaamisella oli myönteisiä vaikutuksia erityisesti sellaisten korealaisten asenteisiin, joilla ei ollut mahdollisuutta tavata amerikkalaisia kasvotusten.

Parasosiaaliset kohtaamiset vieraan kanssa vähentävät häntä kohtaan koettua ahdistusta (intergroup anxiety, jatkossa IA) (Visintin ym., 2017). Pettigrewn (1998) mukaan ahdistus on erityisen voimakasta, kun jonkin ominaisuuden perusteella itsensä eri ryhmiin lukevat ihmiset tapaavat ensimmäisen kerran. Tässä tutkimuksessa vieraan kohtaamisen aikaansaamaa ahdistusta tarkastellaan katsojien implisiittisinä, tunneperustaisina reaktioina (ks. esim. Gudykunst, 1998; Stephan, 2014), sillä virtuaalitodellisuuden on havaittu vaikuttavan erityisesti katsojien tunnereaktioihin (Hasler ym., 2014).

Parasosiaaliset kohtaamiset voivat syventyä parasosiaalisiksi suhteiksi. Parasosiaalinen suhde muodostuu, kun katsoja tuntee yhteenkuuluvuutta hahmoon ja se jatkuu pidempään kuin hetkellinen kohtaaminen (Cohen, 2009). Ahdistuksen väheneminen on yhteydessä kognitiivisiin, affektiivisiin ja käyttäytymistä koskeviin reaktioihin ja asenteisiin, ja siten edelleen parasosiaalisen suhteen vahvistumiseen (Schramm \& Hartmann, 2008; Shim ym., 2012). Kohtaamisten aikaansaamat eksplisiittiset reaktiot ovat puolestaan yhteydessä kohtaamisen aiheuttamiin ahdistuksen tunteisiin (Turner ym., 2007).

Schiappan ym. (2005) mukaan suhteen muodostumisen kannalta parasosiaalisissa kohtaa- 
misissa katsojille tärkeää on koettu samankaltaisuus, puoleensavetävyys sekä epävarmuuden väheneminen. Erityisesti asenteiden samankaltaisuus on tärkeää parasosiaalisissa (Turner, 1993) ja ryhmien välisissä (Liu ym., 2017) kohtaamisissa. Puoleensavetävyyden osalta sosiaalinen ja tehtäväkeskeinen puoleensavetävyys on todettu merkittävimmiksi parasosiaalisen suhteen kehittymisen kannalta (Rubin \& McHugh, 1987; Schiappa ym., 2005).

Gudykunstin (1985, 1998) mukaan vieraiden kohtaamisessa osapuolten on ahdistuksen tunteen lisäksi pyrittävä hallitsemaan epävarmuutta, joka on kognitiivinen reaktio. Tässä tutkimuksessa ahdistusta mitataan määrällisin menetelmin tarkoituksena luoda kuva vieraan kohtaamisen aikaansaamista implisiittisistä, tunneperustaisista reaktioista. Laadullisella aineistolla puolestaan valotetaan katsojien eksplisiittisiä, sanoitettuja epävarmuuksia ja käsityksiä vieraasta.

Koska tutkimuksen fokus osuu kohtaamisen aikaansaamien välittömien reaktioiden ja parasosiaalisen suhteen muodostuksen välimaastoon, käytämme yhdistävää käsitettä parasosiaaliset ilmiöt (ks. Giles, 2002, Tukachinsky \& Stever, 2018). Käsitteellä viittaamme sekä parasosiaalisen kohtaamisen aikaansaamiin tunneperustaisiin muutoksiin ahdistuksessa että muutoksiin katsojien eksplisiittisissä käsityksissä vuorovaikutuksesta ja suhteesta dokumentissa esiintyvän henkilön kanssa. Tutkimuksen fokus on katsojien mielikuvissa vuorovaikutuksesta ja vuorovaikutussuhteesta dokumentin henkilön kanssa. Näin parasosiaalisuus lähestyy kuvitellun vuorovaikutuksen ja intrapersonaalisen viestinnän käsitteitä (Madison \& Porter, 2016). Pettigrewn (1998) kontaktiteorian mukaan vieraiden kohdatessa oleellista onkin se, voivatko osapuolet kuvitella ystävystyvänsä toistensa kanssa.

\section{Parasosiaaliset ilmiöt immer- siivisissä virtuaaliympäristöissä}

Uudet immersiiviset virtuaaliympäristöt (IVY) synnyttävät mielenkiintoisen kontekstin parasosiaalisille ilmiöille. Rubinin (2018) mukaan tärkein kysymys on se, miten kehittyvä virtuaalitodellisuusteknologia tulee vaikuttamaan vuorovaikutukseen ja ihmissuhteisiin. IVYssä katsojalle välittyy kokemus siitä, että hänelle aistien kautta havaittavissa oleva "maailma" ei ole keinotekoinen (Blascovich ym., 2002, s. 105). Immersiivisen teknologian avulla katsoja ja katsottava jakavat yhteisen ympäristön. IVYssä kohtaaminen ottaa askeleen lähemmäksi kasvokkaista vuorovaikutusta.

Aikaisempi, vielä vähäinen tutkimuskirjallisuus osoittaa, että immersiivisyys vahvistaa katsojien empaattisia reaktioita (Herrera ym., 2018; van Loon ym., 2018) ja kokemusta läsnäolosta (Cummings \& Bailenson, 2016). Immersio siis vaikuttaisi tekevän audiovisuaalisen materiaalin seuraamisesta intensiivisempää, jolloin voidaan olettaa, että myös parasosiaaliset ilmiöt vahvistuvat. IVYjä ei kuitenkaan vielä ole juurikaan tarkasteltu parasosiaalisuuden näkökulmasta. Liebersin ja Schrammin (2019) mukaan nimenomaan parasosiaalisten ilmiöiden tutkiminen uusissa medioissa on erityisen ajankohtaista.

Tässä tutkimuksessa hyödynnämme IVYä nimeltä Dinnertime360, jossa katsoja pääsee istumaan yhteiseen päivällispöytään vieraan kanssa. Vieraalla tarkoitamme dokumentissa esiintyvää oikeaa henkilöä, jota katsoja ei ole tavannut aikaisemmin ja jonka saatetaan havaita omaavan useita itsestä poikkeavia ominaisuuksia, kuten etninen tausta. Toinen IVYssä esiintyvistä henkilöistä on Palestiinasta Suomeen muuttanut Muhammed ja toinen on suomensomali Habiba. Etnisen taustan lisäksi erilaisuutta 
(tai samanlaisuutta) voivat katsojalle edustaa myös muut ominaisuudet, kuten henkilön ikä, ammatti, uskonto, perhestatus tai asenteet.

Materiaali on viestinnän näkökulmasta kiinnostava, koska konteksti rakentuu arkipäiväisen vuorovaikutustilanteen, vieraana päivällispöydässä istumisen, ympärille. Verrattuna esimerkiksi immersiiviseen uutiskerrontaan, jossa katsoja vierailee muuten saavuttamattomissa olevissa paikossa, tutkimusasetelmassa katsoja kokee arkisen vuorovaikutustilanteen IVYn avulla.

\section{Tutkimustehtävä ja tutkimuskysymykset}

Tutkimuksessa tarkastellaan määrällisesti ahdistuksen tunnetta (IA), joka katsojalle syntyy IVYssä esiintyvän henkilön kohtaamisesta ennen ja jälkeen parasosiaalista kohtaamista. Määrällisellä aineistolla pyritään valottamaan erityisesti kohtaamisen aikaansaamia implisiittisiä, tunneperustaisia reaktioita katsojassa:

TK1: Millaisia muutoksia koetussa ahdistuksessa (IA) tapahtuu katsojan ja IVYssä esiintyvän henkilön parasosiaalisessa kohtaamisessa?

Tämän lisäksi tutkimuksessa tarkastellaan parasosiaalisen kohtaamisen yhteyttä katsojien eksplisiittisiin, sanoitettuihin käsityksiin vuorovaikutuksesta ja suhteen muodostumisesta IVYssä esiintyvään henkilöön (asteikolla negatiivinen, neutraali, positiivinen):

TK2: Millaisia käsityksiä (negatiivinen, neutraali, positiivinen) katsojilla on vuorovaikutuksesta ja suhteen muodostumisesta IVYssä esiintyvän henkilön kanssa ennen parasosiaalista kohtaamista ja sen jälkeen?
Laadullisen aineiston avulla tutkimus selvittää, millaiset interpersonaaliset tekijät eli parasosiaaliset ilmiöt ovat merkityksellisiä kohtaamisessa. Myös kolmas tutkimuskysymys valottaa parasosiaalisen kohtaamisen katsojissa aikaansaamia eksplisiittisiä reaktioita:

TK3: Millaisia parasosiaalisten ilmiöiden piirteitä on havaittavissa katsojien vapaamuotoisissa vastauksissa?

\section{Tutkimuksen toteuttaminen}

\section{Immersiivinen virtuaaliympäristö}

Dinnertime360 on immersiivinen virtuaaliympäristö, joka sisältää 360-kuvia, 360- ja stereoskooppisia videoita ja vuorovaikutteisuutta. Dinnertime360ssa katsoja pääsee "istumaan" vieraiden henkilöiden ruokapöytään ja voi liikkua 360-kuvassa itsenäisesti. Katsoja voi klikata pöydässä olevia kuvakkeita, joiden kautta hän pääsee tutustumaan ruokaresepteihin ja kuulee videolla, kun henkilö kertoo itsestään. Lisäksi katsojaa pääsee vierailemaan henkilön ruokapöydässä stereoskooppisessa 360-videossa VR-lasien avulla.

Tutkimuksessa hyödynsimme Muhammedin ja Habiban tarinoita. Muhammed on leski-isä, joka on muuttanut Suomeen Palestiinasta. Hän on ammatiltaan kokki, mutta Suomessa hän ajaa taksia. Muhammed puhuu dokumentissa englantia ja arabiaa. Hän muun muassa kertoo, että vaimonsa kuolinpäivänä hän ja tyttärensä sytyttävät kynttilän. Habiba puolestaan on suomensomali ja puhuu dokumentissa suomea. Hänellä on seitsemän lasta ja hän työskentelee hyväntekeväisyysjärjestössä. Dokumentissa Habiba kertoo arkipäiväisistä syrjinnän kokemuksista. 


\section{Menetelmät}

Osallistujat rekrytoitiin tutkimuspyynnöllä, jossa pyydettiin osallistumaan "videodokumenttien viestintää ja sen vaikutuksia" tarkastelevaan tutkimukseen. Osallistumisesta sai elokuvalipun. Tutkimuksessa toteutettiin kaksi osatutkimusta ja niihin osallistui yhteensä 51 henkilöä (Muhammed/T1 n = 25 ja Habiba/T2 $\mathrm{n}=26)$. Kaikista osallistujista naisia oli $35(\mathrm{Mu}-$ hammed 19, Habiba 16), miehiä 14 (Muhammed 6, Habiba 8) ja 2, jotka sijoittivat itsensä muu-ryhmään. Muhammedin IVYn katsojat olivat keskimäärin 27-vuotiaita (19-41) ja Habiban 28-vuotiaita (20-55).

Tutkimuksessa kerättiin määrällistä ja laadullista kyselylomakeaineistoa. Esikyselyssä osallistujat vastasivat kysymyksiin henkilön valokuvan perusteella. Jälkikyselyssä samoihin kysymyksiin vastattiin Dinnertime360n katselun perusteella. Tutkimus toteutettiin häiriöttömässä koetilassa ja vastausaika vaihteli 30-60 minuuttiin.

Ahdistus (IA). Ryhmien välistä ahdistusta mitattiin Stephanin ja Stephanin (1985) IA-mittarilla (ks. myös Stephan, 2014). Mittari on laajasti käytetty ja sillä on tutkittu kohtaamisia eri ryhmien edustajien välillä (esim. Bagci ym., 2018; Shim ym., 2012; Visintin ym., 2017). Osallistujat täyttivät kyselyn ennen dokumenttia ja sen jälkeen. Mittarissa on 11 väittämää. Osallistujaa pyydetään arvioimaan seitsemän portaisella asteikolla, missä määrin hän saattaisi tuntea kyseisiä tunteita, jos hän tapaisi IVYssä esiintyvän henkilön. Kyselyssä tunteet ovat luottavainen, kiusaantunut, epävarma, onnellinen, hyväksytty, itsevarma, ärsyyntynyt, kärsimätön, puolustuskannalla, epäluuloinen, varovainen. Mittari käännettiin englannista suomeen ristiin kääntämällä se tutkimusaihetta tuntemattoman avustajan kanssa.
Avoimet kysymykset. Avoimissa kysymyksissä osallistujaa pyydettiin kuvailemaan valokuvan ja myöhemmin dokumentin katsomisen perusteella hänen mielikuvaansa siitä, millaista olisi keskustella kyseisen henkilön kanssa ja olla hänen tuttavansa. Huomio kiinnittyi osallistujan mielikuviin siitä, millaista olisi olla vuorovaikutuksessa ja vuorovaikutussuhteessa henkilön kanssa.

Analyysi. Analyysimetodeina olivat määrällinen, kuvaileva määrällinen ja sisällöllinen analyysi. Määrällisessä aineistossa IA-mittariin (ennen/jälkeen) annetuista vastauksista muodostettiin summamuuttujat (Esikysely-IA, Jälkikysely-IA). Vastausten jakautumista normaalijakaumalle arvioitiin käyttämällä Shapiro-Wilk testiä ( $p>$.05). Jälkikysely-IAn jakaumat olivat epänormaaleja kummassakin osatutkimuksessa, joten IA-muuttujien keskiarvojen vertailussa käytettiin Wilcoxonin merkittyjen sijalukujen testiä.

Kuvailevassa määrällisessä analyysissä vastaukset eriteltiin ensin analyysiyksiköihin. Analyysiyksikkönä käytettiin lausumaa. Koodit nimettiin ensin lähelle alkuperäisiä lausumia. Koodeja saatiin yhteensä 269 (T1 Muhammed:116, T2 Habiba:153). Seuraavaksi toteutettiin aineistolähtöinen analyysi, jonka jälkeen koodit ryhmiteltiin kolmeen kategoriaan: negatiivisiin, neutraaleihin ja positiivisiin. Esimerkiksi vastaukset kysymykseen kuvitellusta vuorovaikutuksesta henkilön kanssa jakautuivat seuraavasti: "antoisaa, koska elämänkokemusta" (positiivinen), "normaalia" (neutraali) ja "hän voisi asennon perusteella olla kärkäs” (negatiivinen). Kuvailevassa määrällisessä analyysissä käytettiin rinnakkaiskoodausta. Vastauksista rinnakkaiskoodattiin $22 \%$ ja koodaajien välinen yhdenmukaisuus oli $91 \%$. Analyysien erimielisyydet ratkaistiin keskustelemalla. Lo- 
puksi kunkin kategorian sisältämät koodit teemoiteltiin sisällöllisesti.

\section{Tulokset}

Tutkimuksen määrälliset ja kuvailevat määrälliset tulokset on esitetty kahdessa taulukossa. Sisällöllisen analyysin tulokset sisältävät suoria lainauksia aineistosta, ja ne on merkitty tekstiin lainausmerkeillä.

\section{Tutkimus 1: Muhammed}

Parasosiaalinen kohtaaminen ja muutos ahdistuksessa (IA). Ahdistuksen muutosta tarkasteltiin mittaamalla jokaisen katsojan yksilökohtainen prosentuaalinen alenema muuttujassa dokumentin katsomisen jälkeen. $\mathrm{Mu}$ hammedin ryhmässä $(n=25)$ ahdistus aleni keskimäärin 32,93\% $(\mathrm{s}=18,25)$. Taulukossa 1 on esitetty ahdistuksen suhteellisen vähenemisen lisäksi osallistujien ahdistus ennen ja jälkeen dokumentin katsomisen. Tulokset osoittavat, että ahdistus oli vähäisempää dokumentin katsomisen jälkeen $(\mathrm{Md}=24, \mathrm{ka}=25,16, \mathrm{~s}=$ $8,74)$ kuin ennen sitä $(\mathrm{Md}=39, \mathrm{ka}=38,08, \mathrm{~s}=$ 9,58) $(\mathrm{Z}=1, \mathrm{p}<0,001)$.

\section{Parasosiaalinen kohtaaminen ja muutos kä-} sityksissä. Vastaajien käsitykset siitä, millaista olisi olla vuorovaikutuksessa tai vuorovaikutussuhteessa Muhammedin kanssa muuttuivat positiivisemmiksi dokumentin katsomisen jälkeen (ks. Taulukko 2). Lisäksi neutraalien ja negatiivisten käsitysten osuus väheni. Tulokset on esitetty prosentteina ja prosenttiyksikköinä.

\section{Katsojille merkitykselliset parasosiaaliset} ilmiöt. Ennen dokumentin katsomista osallistujat arvelivat vuorovaikutuksen Muhammedin kanssa olevan opettavaista ja mielenkiintoista. Keskustelu olisi mielenkiintoista, koska "hänellä olisi varmasti enemmän elämänkokemusta ja hyvin erilainen kulttuuritausta kuin minulla.” Keskustelun ajateltiin myös olevan pääsääntöisesti mukavaa, vaikka esimerkiksi Muhammedin ikä esitettiin tekijäksi, joka saattaisi vaikeuttaa kanssakäymistä. Vastaukset sisälsivät myös epäröintiä: olisiko heillä yhteisiä kiinnostuksen kohteita, poliittisesti samansuuntaisia ajatuksia tai vaikeuttaisiko "kielimuuri" keskustelua? Katsojat ilmaisivat, että suhteen rakentuminen ja vuorovaikutus riippuisi pitkälti siitä, millainen luonne Muhammedilla olisi.

Dokumentin katsomisen jälkeen positiivisesti suhtautuvat katsojat kuvasivat Muhammedin kanssa vuorovaikutuksessa olemista mielenkiintoiseksi, merkitykselliseksi ja koskettavaksi. Vastaajien mukaan keskusteleminen olisi mielenkiintoista, koska heillä olisi paljon puhuttavaa elämästä, kulttuurista, uskonnosta ja ruoanlaitosta. Suhde Muhammediin olisi merkityksellinen, koska hän on lämmin, avoin tunteistaan ja hänellä on paljon elämänkokemusta. Katsojia kosketti, että Muhammed on kokenut paljon vaikeita asioita, ja he tunsivat sympatiaa häntä kohtaan. Yksi osallistuja esimerkiksi ajatteli voivansa auttaa Muhammedia hänen tyttärensä hoidossa. Potentiaalista suhdetta kuvattiin antoisaksi ja turvalliseksi, koska $\mathrm{Mu}$ hammed välittää ja auttaa muita. Muhammed koettiinkin ihmiseksi, joka voisi myös auttaa katsojaa vaikean paikan tullen.

Kuvan perusteella Muhammediin neutraalisti suhtautuneet olettivat vuorovaikutuksen olevan asiapitoista: "Uskoisin, että hänen kanssaan tulisi käytyä varsin asiallista, faktoihin perustuvaa ja mahdollisesti arkipäiväistä keskustelua." Osallistujat arvelivat, että arvomaailmojen sekä taustan, sukupuolen- ja luonteenpiirteiden erot haastaisivat vuorovaikutussuhteen. Dokumentin jälkeen neutraaleissa vastauksissa korostettiin vuorovaikutuksen "tavallisuutta". Yksi osallistujista kuvasi mahdollista vuorovai- 
kutussuhdetta näin: "Muhammed tekisi hyvää ruokaa, kun menisi kylään. Kyselisi kuulumisia, mutta keskustelut voisivat olla hieman syvällisiäkin.”

Ennen dokumenttia siihen negatiivisesti suhtautuvat sanoivat kielimuurin ja omien ennakkoasenteiden olevan syy käsityksiinsä, kuten eräs osallistuja kirjoitti:

Itselläni ei toistaiseksi ole oikein ulkomaalaisia tuttavia ja jollain tasolla hieman pelkään sitä, kuinka hyvin ymmärtäisimme toisiamme mahdollisen kielimuurin ja kulttuurierojen takia.
Dokumentin jälkeen hyvin harva kuitenkin suhtautui Muhammediin negatiivisesti. Useassa vastauksessa näkyi käsitys vuorovaikutuksen positiivisuudesta erilaisista kanssakäymisen sujuvuuteen liittyvistä huolista huolimatta. Yksi osallistuja esimerkiksi kirjoitti, että vuorovaikutus olisi "edelleen hieman outoa ikäeron vuoksi ja eri elämäntilanteen vuoksi”. Myös Muhammedin uskonnollisuus koettiin mahdolliseksi haasteeksi, ja yksi osallistuja pohti, olisiko Muhammedin kokemusten kuuleminen liian raskasta.

Taulukko 1. Ahdistus (IA) ennen ja jälkeen Muhammedin dokumentin sekä sen suhteellinen väheneminen $(\mathrm{n}=25)$

$\begin{array}{lcc}\text { Muuttuja } & \text { Keskiarvo } & \text { Keskihajonta } \\ \text { Esikysely IA } & 38.08 & 9.58 \\ \text { Jälkikysely IA }{ }^{* *} & 25.16^{\mathrm{a}} & 8.74 \\ \text { IA suhteellinen väheneminen* } & 32.93 \% & 18.25 \\ { }^{*} \mathrm{p}<.05 .{ }^{* *} \mathrm{p}<.01 . & & \\ { }^{a} \text { Vastaukset eivät noudattaneet normaalijakaumaa } & \end{array}$

Taulukko 2. Vastaajien käsitykset vuorovaikutuksesta ja vuorovaikutussuhteesta Muhammedin kanssa $(\mathrm{n}=25)$

\begin{tabular}{lccc} 
Käsitykset & Esikysely & Jälkikysely & Muutos \\
\hline positiivinen & $41 \%$ & $86 \%$ & $+45 \%-y$ \\
neutraali & $41 \%$ & $10 \%$ & $-31 \%-y$ \\
negatiivinen & $18 \%$ & $3 \%$ & $-15 \%-y$ \\
YHTEENSÄ & $100 \%$ & $99 \%$ &
\end{tabular}


Tutkimus 2: Habiba

Parasosiaalinen kohtaaminen ja muutos ahdistuksessa (IA). Ahdistuksen muutosta tarkasteltiin mittaamalla jokaisen osallistujan yksilökohtainen prosentuaalinen alenema muuttujassa katselun jälkeen. Habiban ryhmässä $(\mathrm{n}=26)$ ahdistus aleni keskimäärin 20,54 \% $(s=17,22)$. Taulukossa 3 on esitetty ahdistuksen suhteellisen vähenemisen lisäksi osallistujien ahdistus ennen ja jälkeen dokumentin katsomisen. Tulokset osoittavat, että ahdistus oli vähäisempää dokumentin katsomisen jälkeen ( $\mathrm{Md}=$
26, $\mathrm{ka}=26,19, \mathrm{~s}=7,09)$ kuin ennen sitä $(\mathrm{Md}=$ $32, \mathrm{ka}=33,23, \mathrm{~s}=7,03)(\mathrm{Z}=16, \mathrm{p}<0,001)$.

Parasosiaalinen kohtaaminen ja muutos käsityksissä. Vastaajien käsitykset vuorovaikutuksesta tai vuorovaikutussuhteesta Habiban kanssa muuttuivat positiivisemmiksi dokumentin jälkeen (ks. Taulukko 4). Myös negatiivisten ja neutraalien käsitysten määrä väheni. Tulokset on esitetty prosentteina ja prosenttiyksikköinä.

Katsojille merkitykselliset parasosiaaliset ilmiöt. Ennen dokumenttia vastaajien positiiviset käsitykset vuorovaikutuksesta Habiban

Taulukko 3. Ahdistus (IA) ennen ja jälkeen Habiban dokumentin sekä sen suhteellinen väheneminen $(\mathrm{n}=26)$

$\begin{array}{lcc}\text { Muuttuja } & \text { Keskiarvo } & \text { Keskihajonta } \\ \text { Esikysely IA } & 33.23 & 7,03 \\ \text { Jälkikysely IA }{ }^{* *} & 26.19^{\mathrm{a}} & 7,09 \\ \text { IA suhteellinen väheneminen } & 20.54 \% & 17,22 \\ { }^{*} \mathrm{p}<.05 .{ }^{* *} \mathrm{p}<.01 . & \\ { }^{\mathrm{a}} \text { Vastaukset eivät noudattaneet normaalijakaumaa } & \end{array}$

Taulukko 4. Vastaajien käsitykset vuorovaikutuksesta ja vuorovaikutussuhteesta Habiban kanssa $(n=26)$

\begin{tabular}{lccc} 
Käsitykset & Esikysely & Jälkikysely & Muutos \\
\hline positiivinen & $70 \%$ & $79 \%$ & $+9 \%-y$ \\
neutraali & $26 \%$ & $19 \%$ & $-7 \%-y$ \\
negatiivinen & $4 \%$ & $1 \%$ & $-3 \%-y$ \\
YHTEENS̈̈ & $100 \%$ & $99 \%$ &
\end{tabular}


kanssa kiteytyivät mielenkiintoisuuteen, miellyttävyyteen ja opettavaisuuteen. Vastaajista olisi mielenkiintoista ja opettavaista saada uusia näkökulmia ja tietoa somalialaisesta kulttuurista. Miellyttävyys syntyi siitä, että Habiba vaikutti lämpimältä ja luotettavalta.

Dokumentin jälkeen vuorovaikutukseen positiivisesti suhtautuvat kuvasivat keskustelua Habiban kanssa mielenkiintoiseksi ja mielekkääksi. Osallistujat kokivat omaavansa samankaltaisen maailmankatsomuksen kuin Habiba, mikä tekisi keskustelusta mielekästä. Keskustelussa erilaiset taustat voitaisiin jättää taka-alalle, kuten yksi osallistuja kirjoitti: "Voisimme puhua kaikenlaisista asioista ja unohtaa 'etniseen taustaamme' liittyvät eromme". Toisaalta Habiban tausta ja kokemus maahanmuuttajataustaisena Suomessa elämisestä koettiin kiinnostavaksi puheenaiheeksi, ja osallistujat ajattelivat vuorovaikutussuhteen Habiban kanssa "silmiä avaavaksi" ja "rikastuttavaksi". Habiba koettiin lämpimäksi ihmiseksi, jonka ystävänä olisi hyvä olla:

Habiban tuttavuus olisi varmasti täynnä rakkautta, hän vaikutti videoiden perusteella hyvin lämpimältä henkilöltä. Uskoisin, että pitäisimme tiiviisti yhteyttä ja kyselisimme toisiltamme usein, mitä kuuluu. Olemme tietenkin hyvin erilaisessa elämäntilanteessa, minä olen nuori opiskelija ja hän on työssä käyvä monen lapsen äiti.

Kuvan perusteella neutraalisti suhtautuneet ajattelivat, että heidän tulisi sietää eriäviä mielipiteitä keskustellessaan Habiban kanssa. Yhden osallistujan mukaan "Habiban kanssa keskustellessa tulisi olla valmis syvällisempään keskusteluun ja kuulemaan hänen näkemyksiään, jotka saattavat erota omasta." Koska vastaajien mukaan vuorovaikutussuhteen etenemistä olisi vaikea ennustaa, suhteen laatu riippuisi siitä, millainen henkilö Habiba on. Tärkeä motiivi suhteen rakentamiselle kuitenkin oli Habiban lämpimyys ja "tavallisuus", kuten eräs osallistuja kiteytti:

Uskon edelleen, että keskusteleminen olisi mielenkiintoista ja kulttuurierot muokkaisivat puheenaiheita. Mutta tietäessäni hänestä nyt hieman enemmän, uskon että keskustelu olisi melko tavallista ja luontevaa arkisista asioista.

Osallistujat löysivät Habiban kanssa paljon yhteisiä kiinnostuksen aiheita, joista voitaisiin keskustella, kuten lapset, äitiys ja "järjestökenttä". Yksi osallistuja kertoi tulevansa suuresta perheestä kuten Habibakin ja uskoi tästä löytyvän yhteistä pohjaa keskustelulle. Toinen kertoi ajattelevansa dokumentin jälkeen, että Habiban kanssa voisi keskustella arkisista asioista, kuten ruoanlaitosta.

Negatiivisissa ennakkokäsityksissä osallistujat ajattelivat vuorovaikutuksen Habiban kanssa olevan haastavaa, jos yhteistä kieltä ei löytyisi. Haastavuus rakentui vastaajien omien sanojen mukaan "kulttuurierojen" synnyttämistä oletetuista eroavaisuuksista. Dokumentin katsomisen jälkeen osallistujat eivät ilmaisseet enää kielteisyyttä Habibaa kohtaan, vaan mielipahaa siitä, että Habiba ja hänen lapsensa ovat kokeneet rasismia. Esimerkiksi yksi osallistuja ajatteli, että suhde Habibaan olisi mutkaton, mutta esitti huolen ympäröivän yhteiskunnan epäoikeudenmukaisuudesta, johon hänen täytyisi Habiban ystävänä puuttua: "Ikävä kyllä uskon, että joutuisin joissain tilanteissa puolustamaan häntä epäoikeudenmukaisissa tai rasistissa tilanteissa ulkopuolisten kanssa."

\section{Johtopäätökset}

Tutkimuksessa tarkasteltiin immersiivistä dokumenttia, Dinnertime360, jossa katsoja tutustuu itselleen vieraaseen ihmiseen immersiivises- 
sä virtuaaliympäristössä (IVY), parasosiaalisten kohtaamisten ja ilmiöiden näkökulmasta. Tulokset osoittavat, että dokumentin katsominen vähensi katsojien ahdistuksen tunteita ja lisäsi myönteistä suhtautumista vieraaseen ihmiseen. Muutos katsojien suhtautumisessa liittyi heidän käsityksiinsä vuorovaikutuksesta ja vuorovaikutussuhteesta dokumentin henkilön kanssa. Tulokset osoittavat immersiivisen tarinankerronnan potentiaalin kielteisten tunteiden ja ennakkokäsitysten vähentäjänä.

Tutkimuksessa käytetty IA-mittari osoitti, että dokumentin katsominen vähensi katsojien ahdistuksen tunteita. Haslerin ym. (2014) mukaan virtuaalitodellisuus aikaansaa erityisesti tunnetason muutoksia katsojassa. Aikaisemmassa tutkimuksessa on keskitytty erityisesti IVYjen aiheuttamiin positiivisiin tunnereaktioihin, kuten empatiaan. Virtuaalitodellisuutta onkin kutsuttu "empatiakoneeksi" (esim. Herrera ym., 2018), koska se mahdollistaa katsojalle konkreettisen toisen asemaan asettumisen ja empatian tunteiden heräämisen (Hasler ym., 2017). Tämä tutkimus osoittaa, että IVY voi yhtä lailla myös vähentää kielteisiä tunteita, kuten IVYssä kohdattuja henkilöitä kohtaan koettua ahdistusta.

Tulokset osoittavat, että ahdistusta voidaan vähentää IVYssä interpersonaalisten prosessien kautta. Batsonin ym. (1997) mukaan myöskään empatiassa ei ole kyse toisen kokemusmaailman omaksumisesta, vaan myötäelämisestä toisen, erillisen yksilön kanssa. Tämä tutkimus osoittaa, että myös ahdistuksen väheneminen on mahdollista saavuttaa toisen, erillisen ihmisen parasosiaalisen kohtaamisen kautta, sen sijaan että katsojan täytyisi esimerkiksi avattaren avulla "kävellä toisen kengissä". Jos IVYillä halutaan vähentää kielteisiä ja lisätä myönteisiä tunnereaktiota katsojissa, on siis tärkeää kiinnittää huomiota myös parasosiaalisen suhteen muodostumista edesauttaviin interpersonaalisiin elementteihin.

Myös katsojien eksplisiittiset, sanallistetut reaktiot muuttuivat myönteisemmiksi parasosiaalisen kohtaamisen jälkeen. Erilaisuus, hyödyllisyys ja samankaltaisuus olivat merkityksellisimpiä interpersonaalisia elementtejä parasosiaalisessa kohtaamisessa.

Katsojat kokivat erilaisuutta dokumentissa esiintyvien henkilöiden kanssa elämäntilanteesta, iästä, kielestä, sukupuolesta, uskonnosta ja oletetusta arvopohjasta. Myönteisesti suhtautuville katsojille koettu erilaisuus motivoi heitä muodostamaan vuorovaikutussuhteen dokumentin henkilön kanssa. Siasin ym. (2008) mukaan tulkittu kulttuurinen erilaisuus voikin olla vuorovaikutukseen kannustava tekijä. Vuorovaikutukseen motivoiva erilaisuus voidaan nähdä myös osana vieraan ihmisen puoleensavetävyyttä. Kokemus audiovisuaalisessa kanavassa esiintyvän henkilön puoleensavetävyydestä on puolestaan havaittu vahvistavan parasosiaalisia ilmiöitä (Knoll ym., 2015).

Dokumentissa esiintyvän henkilön koettu puoleensavetävyys liittyi myös kokemukseen hänen omaamastaan elämänkokemuksesta ja viisaudesta, mikä sai usean katsojan ajattelemaan, että suhde olisi heille hyödyllinen esimerkiksi sosiaalisen tuen muodossa. Muhammedin kohdalla on kiinnostavaa, että osa esitti myös mahdollisuuden auttaa Muhammedia lastenhoidossa. Tuen antaminen on yksi vastavuoroisen suhteen rakentamisen tapa (Kuuluvainen \& Isotalus, 2014). Näin supportiivisuus piirtyy yhdeksi tärkeäksi elementiksi vuorovaikutussuhteen potentiaalia punnittaessa.

Tuloksissa samankaltaisuuden kokemuksen kanssa resonoi katsojien havainto vieraan "tavallisuudesta”, joka liittyi ajatukseen vuoro- 
vaikutuksen tunnistettavuudesta. Tällaisessa vuorovaikutussuhteessa kahviteltaisiin, vierailtaisiin toisen luona ja laitettaisiin yhdessä ruokaa eli tehtäisiin tavallisia asioita. Toisin sanoen dokumentin katsojat kokivat, että vieraan ei tarvitse olla samanlainen - saman ikäinen, saman maalainen tai samassa elämäntilanteessa - kunhan vuorovaikutus hänen kanssaan olisi turvallista. Dinnertime360ssa vieras ei jää perinteisen dokumenttikerronnan tavoin ulkopuolisen tarkkailun kohteeksi, vaan IVY mahdollistaa immersiivisen kokemuksen universaalisesti jaetusta arkisesta tapahtumasta, ruokailutilanteesta. Tulokset osoittavat, miten katsojien huomio siirtyi dokumentissa esiintyvän ihmisen havaitusta ulkoryhmäjäsenyydestä interpersonaalisen tason ilmiöihin. Immersiivisyys hälventää rajaa katsojan ja katsottavan - ja samalla sisä- ja ulkoryhmän välillä.

Montgomeryn ja Zhangin (2017) mukaan ryhmien välisissä suhteissa asenteisiin vaikuttavat myös odotukset vuorovaikutuksen sujuvuudesta. IVYjä voisi kehittää vahvistamaan katsojan kokemusta turvallisesta, "tavallisesta" ja sujuvasta vuorovaikutuksesta vieraan kanssa. Tavoitteena voisi olla tarjota katsojalle interpersonaalisen tason kokemus omasta vuorovaikutusosaamisesta kohtaamisessa sekä dokumentissa esiintyvän henkilön ystävällisyydestä ja lähestyttävyydestä.

Interpersonaalisen tason prosessit IVYissä, kuten samankaltaisuuden ja toisen hyväntahtoisuuden havaitseminen toimivat myös vastavoimana sellaisille kielteisille ryhmien välisille ilmiöille, kuten stereotypiat ja ennakkoluulot. Aikaisempi tutkimus osoittaa, että positiiviset kohtaamiset interpersonaalisella tasolla voivat johtaa asenteiden paranemiseen myös ryhmätasolla (Stephan, 2014). Tällaiset myönteiset parasosiaaliset vuorovaikutuskokemukset olisivat erityisen tärkeitä sellaisille ihmisille, joilla on vahvoja ennakkoluuloja ulkoryhmiä kohtaan.

Myönteiset parasosiaaliset vuorovaikutuskokemukset IVYissä voivat laskea kynnystä kohdata omaan sisäryhmään kuulumattomia - vieraita - myös kasvokkain. Hodsonin ym. (2017) mukaan ulkoryhmää kohtaan koettujen negatiivisten tunteiden väheneminen lisää todennäköisyyttä sille, että yksilö osallistuu kasvokkaiseen vuorovaikutukseen ulkoryhmän jäsenten kanssa tulevaisuudessa. IVYjä voitaisiin käyttää esimerkiksi erilaisissa pedagogisissa ympäristöissä, kuten kouluissa osana suvaitsevaisuuden ja monikulttuurisuuden opetusta. IVYt mahdollistavat vieraiden kohtaamisen interpersonaalisella tasolla myös sellaisilla alueilla ja sellaisille ihmisille, joiden ympäristö on kulttuurisesti ja sosiaalisesti homogeeninen, ja joilla ei esimerkiksi ole mahdollisuutta matkustaa.

Tutkimukseen liittyy useita tuloksia tulkittaessa huomioon otettavia tekijöitä. Ensinnäkin tutkimusjoukko oli suhteellisen pieni ja kaikki osallistujat olivat yliopisto-opiskelijoita. IVY itsessään saattoi myös aiheuttaa jännitystä osallistujissa ja näin käytön yhteydessä vaikuttaa tuloksiin. Voi myös olla, että osallistujat pyrkivät antamaan sosiaalisesti hyväksyttäviä vastauksia, joskin aineiston keruu anonyymin kyselyn avulla oletettavasti vähensi tätä mahdollisuutta. IVYjä tarkasteltiin lisäksi näennäiskokeellisesti ilman kontrolliryhmää, eikä näin voida sanoa missä määrin juuri immersiivisyys aikaansai muutosta. Oleellista onkin ymmärtää IVYt kokonaisuutena, jolloin myös esimerkiksi IVYssä esiintyvien henkilöiden itsestä kertominen on yksi osa immersiivistä ympäristöä. IVYjen kehittämisen näkökulmasta jatkotutkimuksissa tulisi pyrkiä yksilöimään elementit, jotka voimistavat parasosiaalisia ilmiöitä (ks. Sundar ym., 2017). Jatkotutkimuksissa tulisi myös selvittää, kuinka pysyviä muutokset ovat 
ja yleistyivätkö ne koskemaan muita dokumentissa esiintyneen ihmisen sisäryhmän jäseniksi tulkittuja ihmisiä. Lisäksi täytyy muistaa, että IVYt voivat tarjota myös negatiivisia kohtaamisia ja niitä voidaan käyttää apuna haitallisessa asennevaikuttamisessa. Myös nämä kysymykset vaativat jatkotutkimuksia.

Uudet mediat tulevat epäilemättä valtaamaan alaa ihmisten ja ihmisryhmien välisissä suhteissa. Uudet mediat ovat erityisesti nuorten suosiossa, ja IVYt saattavat tarjota nuorille houkuttelevampia parasosiaalisten kohtaamisten paikkoja kuin perinteiset audiovisuaaliset kanavat. IVYjä on tärkeä kehittää myös interpersonaalisesta näkökulmasta, jotta niissä ta- pahtuvat kohtaamiset edistävät suvaitsevaisuutta ennakkoluulojen ja stereotypioiden sijasta. Uudet mediat myös haastavat jo ennestään moniselitteistä parasosiaalisten ilmiöiden teoreettista kenttää (ks. Dibble ym., 2016). Viestinnän tutkimuksella on tärkeä tehtävä auttaa käsitteellistämään ja ymmärtämään virtuaaliympäristöjen mahdollisuuksia vuorovaikutussuhteiden rakentumisen näkökulmasta.

Cummings, J. J., \& Bailenson, J. N. (2016). How immersive is enough? A meta-analysis of the effect of immersive technology on user presence. Media Psychology, 19, 272-309. https://doi.org/10.1080/15213269.2015.1015740

Dibble, J. L., Hartmann, T., \& Rosaen, S. F. (2016). Parasocial interaction and parasocial relationship: Conceptual clarification and a critical assessment of measures. Human Communication Research, 42, 21-44. https://doi.org/10.1111/hcre.12063

Duronto, P. M., Nishida, T., \& Nakayama, S. (2005). Uncertainty, anxiety, and avoidance in communication with strangers. International Journal of Intercultural Relations, 29(5), 549-560. https://doi. org/10.1016/j.ijintrel.2005.08.003

Giles, D. C. (2002). Parasocial interaction: A review of the literature and a model for future research. Media Psychology, 4(3), 279-305. https://doi.org/10.1207/S1532785XMEP0403_04

Gudykunst, W. B. (1985). The influence of cultural similarity, type of relationship, and self-monitoring on uncertainty reduction processes. Communication Monographs, 52(3), 203-217. https://doi.org/10.1080/03637758509376106 
Gudykunst, W. B. (1998). Applying anxiety/ uncertainty management (AUM) theory to intercultural adjustment training. International Journal of Intercultural Relations, 22, 227-250. https://doi. org/10.1016/S0147-1767(98)00005-4

Hasler, B., Hirschberger, G., Shani-Sherman, T., \& Friedman, D. (2014). Virtual peacemakers: Mimicry increases empathy in simulated contact with virtual outgroup members. Cyberpsychology, Behavior and Social Networking, 17(12), 766-771. https://doi. org/10.1089/cyber.2014.0213

Hasler, B. S., Spanlang, B. \& Slater, M. (2017). Virtual race transformation reverses racial in-group bias. PLoS ONE, 12(4), e0174965. https://doi.org/10.1371/journal.pone.0174965

Herrera, F., Bailenson, J., Weisz, E., Ogle, E., \& Zaki, J. (2018). Building long-term empathy: A largescale comparison of traditional and virtual reality perspective-taking. PLoS ONE, 13(10), e0204494. https://doi.org/10.1371/journal.pone.0204494

Hodson, G., Turner, R. N., \& Choma, B. L. (2017). Individual differences in intergroup contact propensity and prejudice reduction. Teoksessa: L. Vezzali \& S. Stathi (toim.), Intergroup contact theory: Recent developments and future directions (s. 8-30). London: Routledge.

Igartua, J., \& Frutos, F. (2017). Enhancing attitudes toward stigmatized groups with movies: Mediating and moderating processes of narrative persuasion. International Journal of Communication, 11, 158-177. https://ijoc.org/index.php/ijoc/article/view/5779

Knoll, J., Schramm, H., Schallhorn, C., \& Wynistorf, S. (2015). Good guy vs. bad guy The influence of parasocial interactions with media characters on brand placement effects. International Journal of Advertising: The Review of Marketing Communications, 34, 720-743. https://doi.org/10.1080/02650487.2015.1009350

Kuuluvainen, V., \& Isotalus, P. (2014). Supporting others - Supporting oneself: Members' evaluations of supportive communication in Al-Anon mutual-aid groups. Studies in Communication Sciences, 14(1), 45-53. http://dx.doi.org/10.1016/j.scoms.2014.03.009

Liebers, N., \& Schramm, H. (2019). Parasocial interactions and relationships with media characters: An inventory of 60 years of research. Communication Research Trends, 38(2), 4-31.
Liu, N., Zhang, Y. B., \& Wiebe, W. T. (2017). Initial communication with and attitudes toward international students: Testing the mediating effects of friendship formation variables. Journal of Intercultural Communication Research, 46(4), 330-345, https://doi.org/10.1080/17475759.2017.1344999

Madison, T. P., \& Porter, L. V. (2016). Cognitive and Imagery Attributes of Parasocial Relationships. Imagination, Cognition and Personality, 35(4), 359-379. https://doi.org/10.1177/0276236615599340

McLaughlin, B., Rodriguez, N. S., Dunn, J. A., \& Martinez, J. (2018). Stereotyped identification: How identifying with fictional Latina characters increases acceptance and stereotyping. Mass Communication and Society, 21(5), 585-605. https://doi.org/10.1080/15205436.2018.1457699

Montgomery, G., \& Zhang, Y. B. (2018). Intergroup anxiety and willingness to accommodate: Exploring the effects of accent stereotyping and social attraction. Journal of Language and Social Psychology, 37(3), 330-349. https://doi.org/10.1177/0261927X17728361

Neuliep, J. W. (2012). The relationship among intercultural communication apprehension, ethnocentrism, uncertainty reduction, and communication satisfaction during initial intercultural interaction: An extension of anxiety and uncertainty management (AUM) theory. Journal of Intercultural Communication Research, 41(1), 1-16. https://doi.org/10.1080/17475759.2011.623239

Paluck, E. L., Green, S. A., \& Green, D. P. (2019). The contact hypothesis re-evaluated. Behavioural Public Policy, 3(2), 129-158. https://doi.org/10.1017/bpp.2018.25

Pettigrew, T. F. (1998). Intergroup contact theory. Annual Review of Psychology, 49(1), 65-85. https://doi.org/10.1146/annurev.psych.49.1.65

Pettigrew, T. F., \& Tropp, L. R. (2005). Allport's intergroup contact hypothesis: Its history and influence. Teoksessa J. F. Dovidio, P. Glick, \& L. P. Rudman (toim.), Reflecting on the nature of prejudice (s. 263-277). Oxford: Blackwell. https://doi.org/10.1002/9780470773963.ch16

Pettigrew, T. F., \& Tropp, L. R. (2006). A meta-analytic test of intergroup contact theory. Journal of Personality and Social Psychology, 90(5), 751-783. https://doi.org/10.1037/0022-3514.90.5.751

Rubin, R. B., \& McHugh, M. P. (1987). Development of parasocial interaction relationships. Journal of Broadcasting and Electronic Media, 31(3), 279-292. https://doi.org/10.1080/08838158709386664 
Rubin, P. (2018). Future presence: How virtual reality is changing human connection, intimacy, and the limits of ordinary life. New York: HarperOne.

Schiappa, E., Gregg, P., \& Hewes, D. (2005). The parasocial contact hypothesis. Communication Monographs, 72(1), 92-115. https://doi.org/10.1080/0363775052000342544

Schiappa, E., \& Gregg, P., \& Hewes, D. (2006). Can one TV show make a difference? Will \& Grace and the parasocial contact hypothesis. Journal of Homosexuality, 51(4), 15-37. https://doi.org/10.1300/J082v51n04_02

Shim, C., Zhang, Y. B., \& Harwood, J. (2012). Direct and mediated intercultural contact: Koreans' attitudes toward U.S. Americans. Journal of International and Intercultural Communication, 5(3), 169-188. https://doi.org/10.1080/17513057.2012.670715

Schramm, H., \& Hartmann, T. (2008). The PSI-process Scales: A new measure to assess the intensity and breadth of parasocial processes. Communications, 33(4), 385-401. https://doi.org/10.1515/COMM.2008.025

Sias, P. M., Drzewiecka, J. A., Meares, M., Bent, R. Konomi, Y., Ortega, M., \& White, C. (2008). Intercultural friendship development, Communication Reports, 21(1), 1-13. https://doi. org/10.1080/08934210701643750

Stephan, W. G. (2014). Intergroup anxiety: Theory, research, and practice. Personality and Social Psychology Review, 18(3), 239-255. https://doi.org/10.1177/1088868314530518

Stephan, W. G., \& Stephan, C. W. (1985). Intergroup anxiety. Journal of Social Issues, 41(3), 157-175. https://doi.org/10.1111/j.1540-4560.1985.tb01134.x

Sundar, S. S., Kang, J., \& Oprean, D. (2017). Being there in the midst of the story: How immersive journalism affects our perceptions and cognitions. Cyperpsychology, behaviorand socialnetworking, 20(11), 672-682. https://doi.org/10.1089/cyber.2017.0271

Tukachinsky, R., \& Stever, G. (2018). Theorizing development of parasocial engagement. Communication Theory, 29(3), 297-318. https://doi.org/10.1093/ct/qty032

Turner, J. R. (1993). Interpersonal and psychological predictors of parasocial interactions with different television performers. Communication Quarterly, 41(4), 443-453. https://doi.org/10.1080/01463379309369904
Turner, R. N., Hewstone, M., \& Voci, A. (2007). Reducing explicit and implicit outgroup prejudice via direct and extended contact: The mediating role of self-disclosure and intergroup anxiety. Journal of Personality and Social Psychology, 93(3), 369-388. https://doi.org/10.1037/0022-3514.93.3.369

van Loon, A., Bailenson, J., Zaki, J., Bostick J., \& Willer, R. (2018). Virtual reality perspective-taking increases cognitive empathy for specific others. PLoS ONE, 13(8), 1-19. https://doi.org/10.1371/journal.pone.0202442

Visintin, E. P., Voci, A., Pagotto, L., \& Hewstone, M. (2017). Direct, extended, and mass-mediated contact with immigrants in Italy: Their associations with emotions, prejudice, and humanity perceptions. Journal of Applied Social Psychology, 47(4), 175-194. https://doi.org/10.1111/jasp.12423

Wong, N. C. H., Lookadoo, K. L., \& Nisbett, G. S. (2017). "I'm Demi and I have bipolar disorder": Effect of parasocial contact on reducing stigma toward people with bipolar disorder. Communication Studies, 68(3), 314-333. https://doi.org/10.1080/10510974.2017.1331928

Wu, Y., Mou, Y., Wang, Y., \& Atkin, D. (2018). Exploring the de-stigmatizing effect of social media on homosexuality in China: An interpersonal-mediated contact versus parasocial-mediated contact perspective. Asian Journal of Communication, 28(1), 20-37. https://doi.org/10.1080/01292986.2017.1324500 